
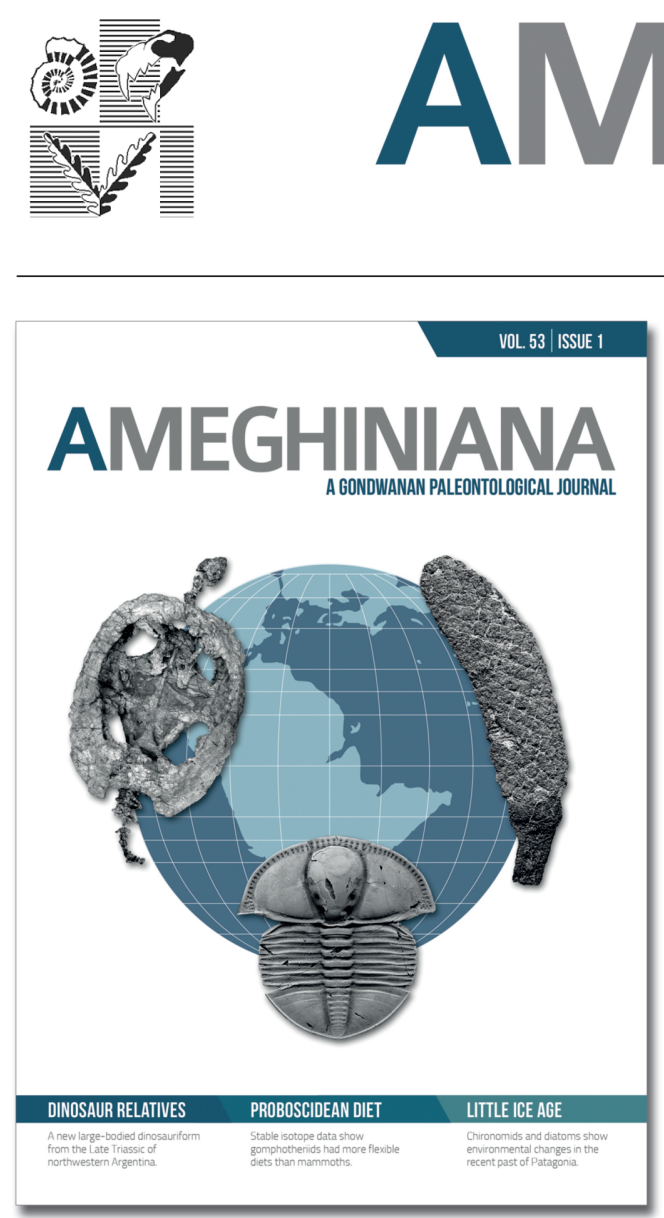

\title{
A NEW PEIROSAURID \\ (CROCODYLIFORMES, MESOEUCROCODYLIA) FROM THE UPPER CRETACEOUS OF PATAGONIA, ARGENTINA
}

FRANCISCO BARRIOS ${ }^{1}$

ARIANA PAULINA-CARABAJAL 1,2

PAULA BONA ${ }^{2,3}$

${ }^{1}$ Museo Municipal Carmen Funes, Av. Córdoba 55, Q8318EBA Plaza Huincul, Neuquén, Argentina.

${ }^{2}$ CONICET, Consejo Nacional de Investigaciones Científicas y Técnicas, Av. Rivadavia 1917, C1033AAJ Ciudad Autónoma de Buenos Aires, Argentina. ${ }^{3}$ División Paleontología Vertebrados, Museo de La Plata, Universidad Nacional de La Plata. Paseo del Bosque s/n, B1900FWA La Plata, Argentina.

Submitted: March $7^{\text {th }}, 2015$ - Accepted: September $3^{\text {rd }}, 2015$

To cite this article: Francisco Barrios, Ariana Paulina-Carabajal, Paula Bona (2015). A new peirosaurid (Crocodyliformes, Mesoeucrocodylia) from the Upper Cretaceous of Patagonia, Argentina. Ameghiniana 53: $14-25$.

To link to this article: http://dx.doi.org/10.5710/AMGH.03.09.2015.2903

PLEASE SCROLL DOWN FOR ARTICLE

Also appearing in this issue:

\section{DINOSAUR RELATIVES}

A new large-bodied dinosauriform from the Late Triassic of northwestern Argentina.

\section{PROBOSCIDEAN DIET}

Stable isotope data show gomphotheriids had more flexible diets than mammoths.

\section{LITTLE ICE AGE}

Chironomids and diatoms show environmental changes in the recent past of Patagonia. 


\title{
A NEW PEIROSAURID (CROCODYLIFORMES, MESOEUCROCODYLIA) FROM THE UPPER CRETACEOUS OF PATAGONIA, ARGENTINA
}

\author{
FRANCISCO BARRIOS ${ }^{1}$, ARIANA PAULINA-CARABAJAL ${ }^{1,2}$ AND PAULA BONA2,3

\begin{abstract}
1Museo Municipal Carmen Funes, Av. Córdoba 55, Q8318EBA Plaza Huincul, Neuquén, Argentina.fbarrios84@gmail.com; a.paulinacarabajal@conicet.gov.ar ${ }^{2}$ CONICET, Consejo Nacional de Investigaciones Científicas y Técnicas, Av. Rivadavia 1917, C1033AAJ Ciudad Autónoma de Buenos Aires, Argentina. ${ }^{3}$ División Paleontología Vertebrados, Museo de La Plata, Universidad Nacional de La Plata. Paseo del Bosque s/n, B1900FWA La Plata, Argentina.
\end{abstract} \\ paulabona26@gmail.com
}

\begin{abstract}
Peirosaurids are a group of Cretaceous continental crocodyliforms from Gondwana. Two species are known from the Neuquén Group in Argentina: Lomasuchus palpebrosus (Portezuelo Formation, late Turonian-early Coniacian) and Gasparinisuchus peirosauroides (Bajo de la Carpa and Anacleto formations, Santonian and early Campanian, respectively). Here, we describe the first peirosaurid from the Cerro Lisandro Formation, Bayomesasuchus hernandezigen. et sp. nov. The material corresponds to a fragmentary skull and mandible. Although fragmentary, this is the most complete crocodyliform specimen recorded for the Cerro Lisandro Formation. In a phylogenetic analysis Bayomesasuchus is depicted in a polytomy together with South American peirosaurids and the African form Hamadasuchus rebouli.
\end{abstract}

Key words. Bayomesasuchus. Peirosauridae. Cerro Lisandro Formation. Cretaceous.

Resumen. UN NUEVO PEIROSÁURIDO (CROCODYLIFORMES, MESOEUCROCODYLIA) DEL CRETÁCICO SUPERIOR DE PATAGONIA, ARGENTINA. Los peirosáuridos constituyen un grupo de crocodiliformes continentales del Cretácico de Gondwana. Para el Grupo Neuquén, Argentina, se conocen dos especies: Lomasuchus palpebrosus (Formación Portezuelo, Turoniano tardío-Coniaciano temprano) y Gasparinisuchus peirosauroides (Formaciones Bajo de la Carpa y Anacleto, Santoniano y Campaniano temprano, respectivamente). Aquí, describimos el primer peirosáurido identificado para la Formación Cerro Lisandro, Bayomesasuchus hernandezi gen. et sp. nov. El material corresponde a cráneo y mandíbula fragmentarios. Aunque fragmentario, este es el espécimen de crocodiliforme más completo registrado para la Formación Cerro Lisandro. En un análisis filogenético, Bayomesasuchus es agrupado en una politomía junto con los peirosáuridos sudamericanos y la forma africana Hamadasuchus rebouli.

Palabras clave. Bayomesasuchus. Peirosauridae. Formación Cerro Lisandro. Cretácico.

LATE Cretaceous Crocodyliformes of Argentina occur mainly in the Neuquén Basin, specifically in the Neuquén Group units (Leanza et al., 2004; Candeiro and Martinelli, 2006; Pol and Gasparini, 2007). Among mesoeucrocodylian notosuchians (Pol et al., 2012), Peirosauridae are a group of Gondwanan Cretaceous continental crocodyliforms (Carvalho et al., 2010) known from South America (Gasparini, 1982; Gasparini et al., 1991; Carvalho et al., 2004, 2007; Leardi and Pol, 2009; Martinelli et al., 2012) and Africa (Buffetaut, 1994; Larsson and Sues, 2007; Sertich and O'Connor, 2014).

The species currently recognized in the Neuquén Group are Lomasuchus palpebrosus Gasparini, Chiappe and Fernán- dez, 1991, and Gasparinisuchus peirosauroides (Martinelli, Sertich, Garrido and Pradeiro, 2012) from the Portezuelo (late Turonian-early Coniacian), Bajo de la Carpa (Santonian) and Anacleto (early Campanian) formations (Garrido, 2010). Fragmentary remains from the Portezuelo Formation were in turn assigned to Peirosauridae (Lio et al., 2014; Barrios and Bona, 2015). Here we present a new peirosaurid species from the Cerro Lisandro Formation (mid-late Turonian), which is also the oldest representative of the family in the Neuquén Group (Fig. 1). The new taxon, Bayomesasuchus hernandezi gen. et sp. nov., is represented by a fragmentary skull and mandibular elements, which allowed us to test its phylogenetic affinities. 


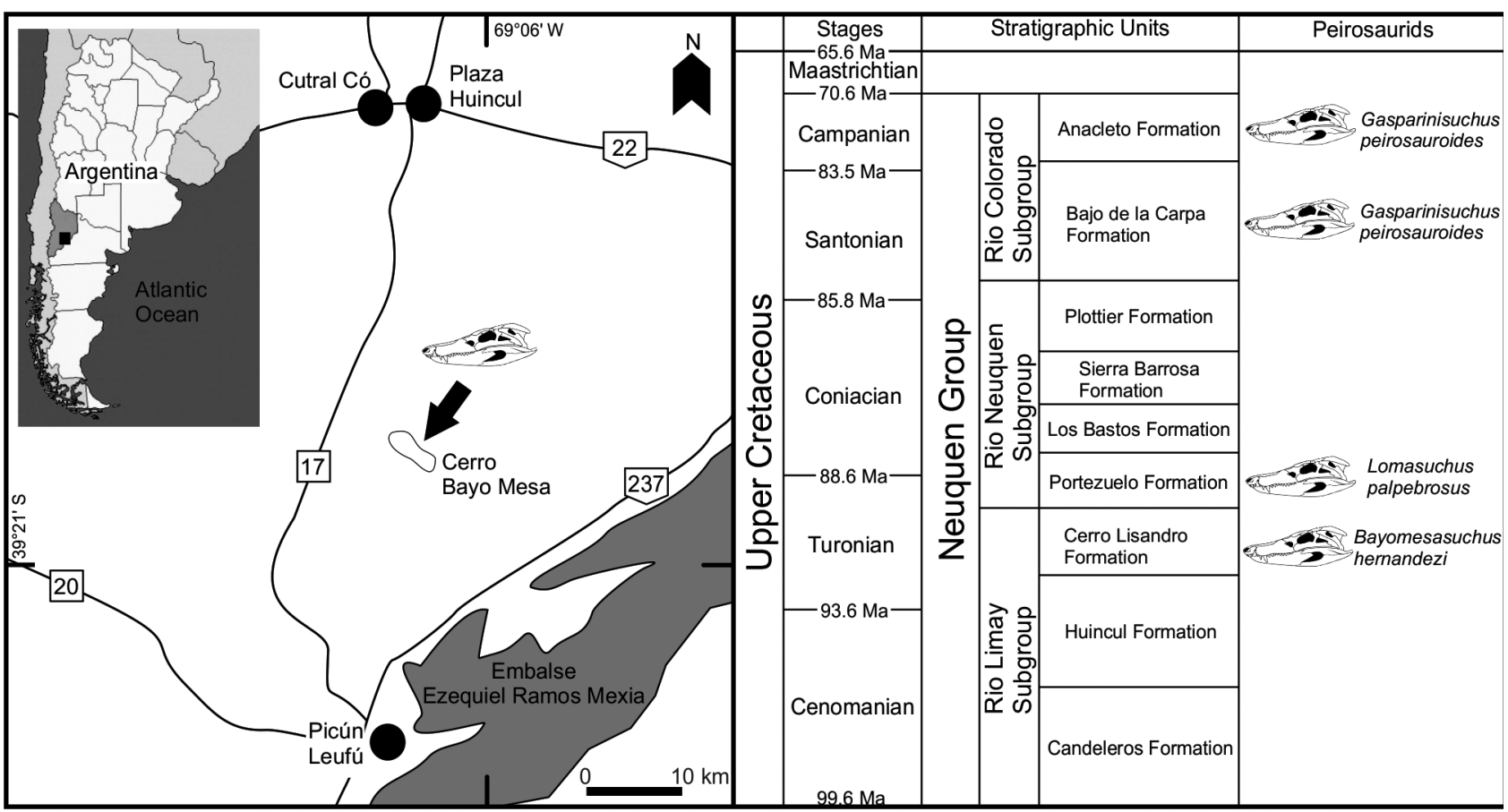

Figure 1. Location map of Bayomesasuchus hernandezi gen. et sp. nov. (MCF PVPH-822) with stratigraphic section showing the provenance of Neuquén Group peirosaurids.

Institutional Abbreviations. CPP, Centro de Pesquisas Paleontológicas L. I. Price, Peirópolis, Brazil; MACN, Museo Argentino de Ciencias Naturales "Bernardino Rivadavia", Buenos Aires, Argentina; MCF, Museo Municipal Carmen Funes, Plaza Huincul, Neuquén, Argentina; MLP, Museo de La Plata, La Plata, Buenos Aires, Argentina; MOZ, Museo Provincial Profesor Dr. J. A. Olsacher, Zapala, Neuquén, Argentina; PVL, Paleontología de Vertebrados Lillo, Instituto Miguel Lillo, San Miguel de Tucumán, Tucumán, Argentina; ZSM, Zoologische Staatssammlung, München, Germany.

\section{SYSTEMATIC PALEONTOLOGY}

Crocodylomorpha Hay, 1930 (sensu Walker, 1970)

Crocodyliformes Hay, 1930 (sensu Clark, 1986)

Mesoeucrocodylia Whetstone and Whybrow, 1983

NotosuchIA Gasparini, 1971 (sensu Pol et al., 2012)

Peirosauridae Gasparini, 1982

\section{Bayomesasuchus gen. nov.}

Bayomesasuchus hernandezi sp. nov.

Figures 2-4
Derivation of name. Bayomesasuchus refers to the Cerro Bayo Mesa locality, Neuquén Province, Argentina; the specific epithet hernandezi was dedicated to the former technician Mr. Daniel Hernández (Museo Carmen Funes, Municipalidad de Plaza Huincul), a resourceful assistant in the fieldwork.

Type material. MCF PVPH-822, fragmentary mandibular symphysis, right fragmentary maxilla, right fragmentary ectopterygoid, left fragmentary postorbital, left fragmentary squamosal, right articular, right fragmentary surangular, left fragmentary palatine and other indeterminate fragments (Figs. 2-4).

Geographic and stratigraphic occurrence. Cerro Bayo Mesa (39 15'02.3" S; 69 12' 59.2" W), 35 km south from Plaza Huincul, Neuquén, Argentina; Cerro Lisandro Formation (mid-late Turonian) (Garrido, 2000, 2010).

Diagnosis. Bayomesasuchus hernandezi gen. et sp. nov. is characterized by the following combination of characters (*autapomorphies): ziphodont and pseudoheterodont (different sizes and morphologies) dentition; dentary with festooned margins, ornamented with pits and grooves; elongated mandibular symphysis extending posteriorly up 
to the 10th alveolus (shared with Montealtosuchus arrudacamposi Carvalho, Vasconcellos and Tavares, 2007), whereas in Hamadasuchus rebouli Buffetaut, 1994, it exceeds that level and in Gasparinisuchus (Martinelli, Sertich, Garrido and Pradeiro, 2012) the mandibular symphysis reaches the 8th alveolus; symphyseal region flattened dorsoventrally and narrow mediolaterally (shared with Montealtosuchus Carvalho, Vasconcellos and Tavares, 2007 and Hamadasuchus Buffetaut, 1994); dorsal and ventral exposure of splenial triangular in shape (shared with other peirosaurids, although the strong wedge-shape is present in longirostrine crocodyliforms such as thalattosuchians, dyrosaurids, pholidosaurids, gavialoids); postorbital with posteroventral process anterior to otic recess and with facet for palpebral bone; squamosal with ornamented and elongate posterolateral process forming an angle of $30^{\circ}$ with dorsal plane (shared with South American peirosaurids and uruguaysuchids); maxillary tooth-row extending caudally beyond anterior margin of suborbital fenestra; maxillary palate with occlusal depressions; surangular with prominent posterolateral ridge; surangular forming part of the mandibular joint (shared with Montealtosuchus but absent in Uberabasuchus terrificus Carvalho, Ribeiro and Ávila, 2004); dentary with diastema between 4th-5th alveoli*; 5th-6th dentary alveoli confluent*; sub-vertical rostrum (shared with other notosuchians).

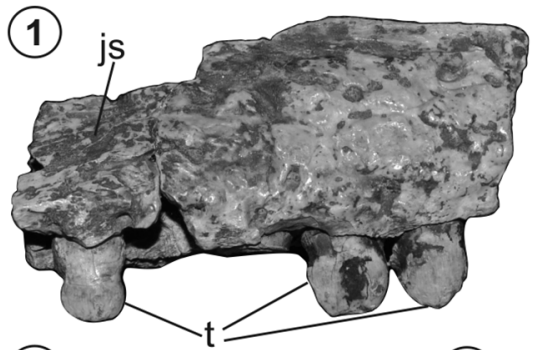

(4)

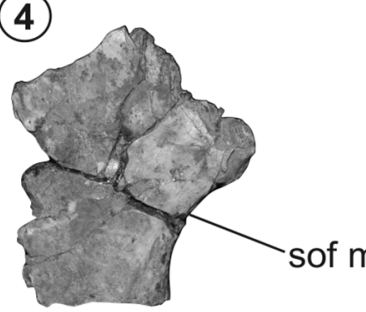

(8)

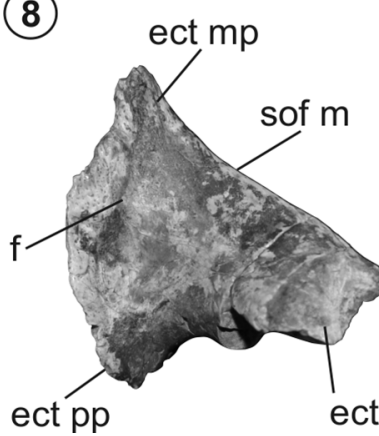

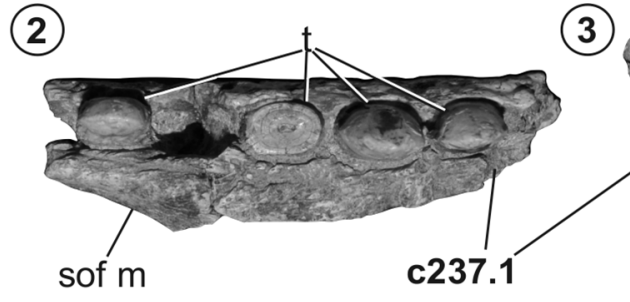

(6)

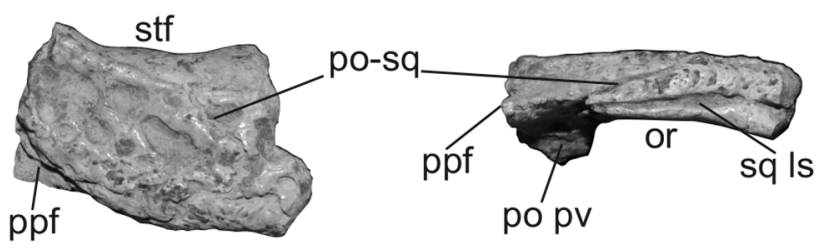

(10)

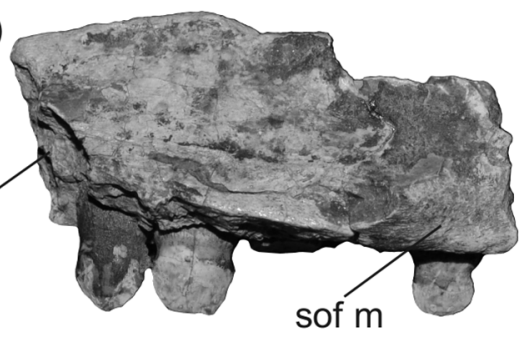

(7)
(11)

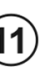

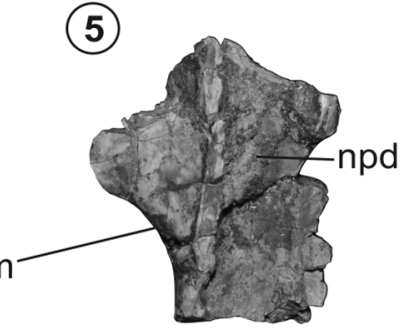

(9)
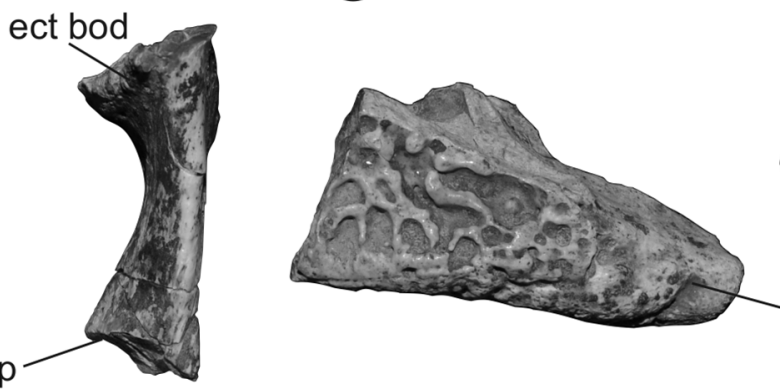

Figure 2. Bayomesasuchus hernandezi gen. et sp. nov., MCF PVPH-822; 1-3, right fragmentary maxilla in 1, lateral, 2, palatal and 3, medial views; 4-5, left fragmentary palatine in 4, palatal and 5, dorsal views; 6-7, left postorbital-squamosal fragment in 6, dorsal and 7, lateral views; 8-9, right fragmentary ectopterygoid in 8, ventral and 9, anterior views; 10-11, left fragmentary squamosal in 10, dorsal and 11, lateral views. Abbreviations: ect bod, ectopterygoid body; ect dsp, ectopterygoid descending process; ect mp, ectopterygoid maxillary process; ect pp, ectopterygoid posterior process; f, foramen; js, jugal suture; npd, nasopharyngeal duct; or, otic recess; po pv, postorbital posteroventral process; po-sq, post-orbital-squamosal suture; ppf, posterior palpebral facet; sof m, suborbital fenestra margin; sq Is, squamosal lateral suture; sq plp, squamosal posterolateral process; stf, supratemporal fossa; t, tooth; c237.1, synapomorphy of Peirosauridae. Scale bar= 2.5 cm. 


\section{DESCRIPTION AND COMPARISONS}

\section{Skull}

Maxilla. A fragment of the posterior region of right maxilla is preserved (Fig. 2.1-3). This is subvertical, as a convex ornamented lateral wall preserving the surface of contact with the jugal posteriorly (Fig. 2.1). Medially, the maxilla is flat anteriorly and slightly concave posteriorly. Ventrally, there are five complete alveoli and one partially preserved, which would correspond to the 7th-12th maxillary teeth, all of them aligned within the alveolar groove (Fig. 2.2). Medially to the first three preserved alveoli there are three depressions that correspond to the occlusal pits for the mandibular teeth. This character also represents a synapomorphy of Peirosauridae (Turner and Sertich, 2010; Sertich and O'Connor, 2014). Posteromedially, part of the anterolateral margin of the right suborbital fenestra is preserved on the palatal shelves of the maxillae. The extension of the maxillary participation in the suborbital fenestra is variable among peirosaurids. In Hamadasuchus the maxilla barely enters into the lateral margin of the suborbital fenestra before being excluded by the palatine anteriorly and ectopterygoid posteriorly (Larsson and Sues, 2007), whereas in Bayomesasuchus, Montealtosuchus, Lomasuchus Gasparini, Chiappe and Fernández, 1991, Gasparinisuchus and Pepesuchus deiseae Campos, Oliveira, Figueiredo, Riff, Azevedo, Carvalho and Kellner, 2011, the maxillary participation in the suborbital fenestra is wide. The tooth-row extends caudally beyond the anterior margin of these fenestrae as in all peirosaurids, contrarily to the condition in advanced notosuchians and baurusuchids (Montefeltro et al., 2011; Pol et al., 2014).

Postorbital and squamosal. The preserved fragment of the articulated postorbital and squamosal corresponds to a section of the anterolateral margins of the left supratemporal fenestra and fossa (Fig. 2.6-7). The postorbital fragment corresponds to the anterolateral corner of the skull table. In dorsal view (Fig. 2.6), the postorbital has a flat and ornamented surface with a convex anterolateral margin, suggesting that the anterolateral corner of the skull table is blunt as in most notosuchians. It also has a descending process that forms the anterior limit of the otic recess, which is partially exposed in lateral view (Fig. 2.7) as in all notosuchians (Pol et al., 2014). In the anterolateral corner (Fig. 2.6-7), the postorbital forms a small portion of the ru- gose anterior process for the articulation with the posterior palpebral. Within the supratemporal fossa the postorbital is smooth and sutured to the squamosal posteriorly. In dorsal view (Fig. 2.6), the anterolateral exposure of the supratemporal fossa is narrow as in Lomasuchus and the African peirosaurids Hamadasuchus and Rukwasuchus yajabalijekundu Sertich and O'Connor, 2014 (Larsson and Sues, 2007: figs.1, 7; Sertich and O'Connor, 2014: fig. 2) but differing from Montealtosuchus (Carvalho et al., 2007: pl. 1) and Uberabasuchus Carvalho, Ribeiro and Ávila, 2004. The postorbital dorsally overlaps the squamosal along an interdigitated suture (Fig. 2.6-7).

The left squamosal is preserved in two fragments (Fig. 2.10-11). The anterior fragment has a flat ornamented dorsal surface that forms the lateral margin of the supratemporal fossa and fenestra (Fig. 2.6). Within the supratemporal fossa the descending lamina is smooth. It forms the roof of the otic recess ventrally (Fig. 2.7, 11). In dorsal view, the posterior fragment has an anteriorly flat ornamented surface with a straight lateral border (Fig. 2.10-11). It is caudolaterally projected forming a prominent posterolateral process (also ornamented) as in most notosuchians (Pol et al., 2014). The posterolateral process of the squamosal has a marked ventral inclination (Fig. 2.11), forming an angle of $30^{\circ}$ with the dorsal plane, a condition similar to that present in all South American peirosaurids (Lomasuchus, Montealtosuchus and Uberabasuchus). This angle is lower than $30^{\circ}$ in African peirosaurids (Hamadasuchus and Rukwasuchus Sertich and O'Connor, 2014). The posterolateral process is anteroposteriorly elongated and bears a wide ventral sulcus, which is roofing the otic recess (Fig. 2.11). The lateral edge of the squamosal has a narrow longitudinal sulcus at the level of the postorbital suture, presumably for the attachment of the muscles associated with an external ear flap, as in extinct and extant crocodyliforms (Shute and Bellairs, 1955; Larsson and Sues, 2007). In occipital view the squamosal preserves part of the surface contacting with the paroccipital process and with the quadrate more anteriorly.

Palatine. A fragment of the left palatine is preserved, in which some characters can be observed (Fig. 2.4-5). Its anterior and posterior ends are missing but it is broader anteriorly. The anterior end of the palatine extends between palatal branches of the maxilla, as in most notosuchians 
except baurusuchids (Montefeltro et al., 2011). The posterolateral border is curved and corresponds to the anteromedial corner of the suborbital fenestra. The suture with the maxillary palatal process is incomplete and part of the contact with its counterpart is broken. The suture with the maxilla is posterolaterally inclined. Dorsomedially, the palatine has a longitudinal arcuate crest that corresponds to the wall of the nasopharyngeal duct.

Ectopterygoid. The right ectopterygoid is T-shaped and the descending process articulating with the pterygoid flanges is missing (Fig. 2.8-9). The anterior process is short and has two articular facets, one for the maxilla and another one for the jugal (Fig. 2.8). The contact surface with the maxilla is flat, short and anteromedially oriented, whereas the surface of contact with the jugal is larger and anteroposteriorly oriented. The body of the ectopterygoid and the base of the descending process have a lateral torsion and are oval in section, with a flat medial surface (Fig. 2.9). A small fora- men pierces the ventral surface where it turns laterally to abut the jugal (Fig. 2.8). The ectopterygoid forms the posterolateral margin of the suborbital fenestra as in many other crocodyliforms.

\section{Mandible}

Dentary. The most complete mandibular fragment corresponds to the symphyseal region, which is eroded at its anterior end (Fig. 3.1-3). The fragment is $54.4 \mathrm{~mm}$ long, 44.5 $\mathrm{mm}$ wide and $15.5 \mathrm{~mm}$ thick. The dentary is ornamented ventrally (Fig. 3.2). Anteriorly, both dentaries join along an elongated mandibular symphysis, which extends back to the level of the 10th alveolus (Fig. 3.1) as in Montealtosuchus. In Hamadasuchus the symphysis extends back to the level of the 11th alveolus (Larsson and Sues, 2007), while in Gasparinisuchus (MOZ Pv-1750) it extends to the level of the 8th alveolus. In the narrow-snout peirosaurids Itasuchus jesuinoi Price, 1955, and Pepesuchus Campos, Oliveira,

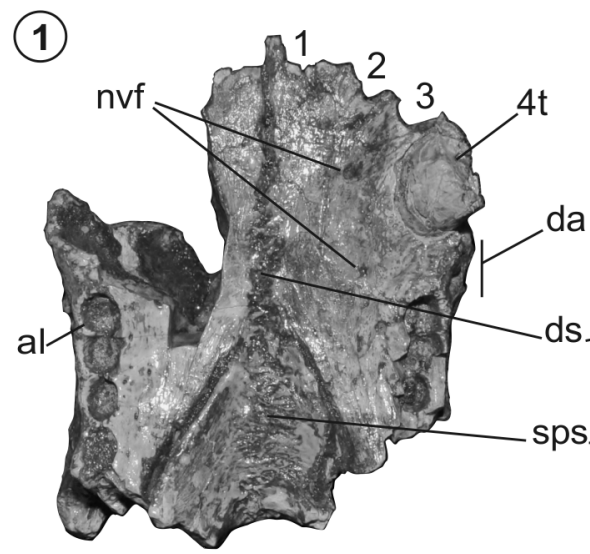

(4)

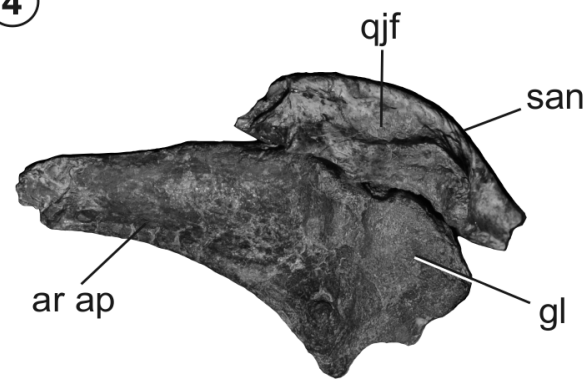

(2)

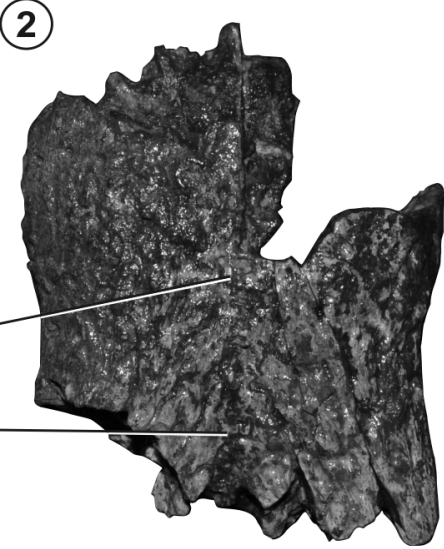

(5)

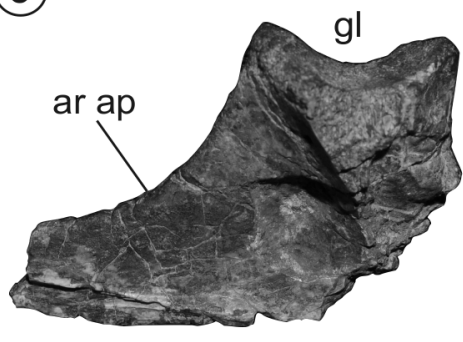

(3)

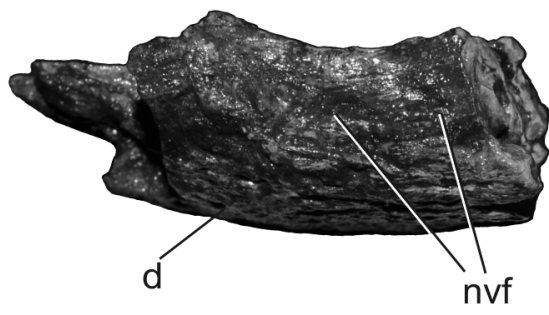

(6)

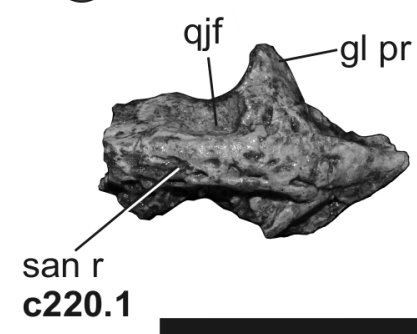

Figure 3. Bayomesasuchus hernandezi gen. et sp. nov., MCF PVPH-822, mandible fragmentary. 1-3, symphyseal region in 1, dorsal, 2, ventral and 3, lateral views; 4-6, right articular-surangular in 4, dorsal, 5, medial and, 6, lateral (mirrored image) views. Abbreviations: al, alveolus; ar ap, articular anterior process; d, dentary; da, diastema; ds, dentary symphysis; gl, glenoid fossa; gl pr, glenoid posterior ridge; nvf, neurovascular foramina; qjf, quadratojugal fossa; san, surangular; san r, surangular ridge; sps, splenial symphysis; 4t, 4th tooth; 1-4 position teeth; c.220.1, synapomorphy of Peirosauridae. Scale bar= $2.5 \mathrm{~cm}$. 
Figueiredo, Riff, Azevedo, Carvalho and Kellner, 2011, the symphysis extends back beyond the level of the 10th alveolus. The symphyseal region in Bayomesasuchus is flattened as in specimens referred to Hamadasuchus (Larsson and Sues, 2007: fig. 6), whereas in Gasparinisuchus it is concave. In Uberabasuchus (CPP 630) and Gasparinisuchus the symphyseal region is thicker than in other peirosaurids (e.g., Bayomesasuchus and Montealtosuchus), whereas in Hamadasuchus it is narrower. In the right dentary the 1st-3rd alveoli are anteriorly damaged, the 4th-5th alveoli are complete and the 6th-7th alveoli are partially preserved (Fig. 3.1). The dentary bulges laterally at the level of the 4th dentary tooth, which is the largest of the series. Alveoli preserved in the left dentary are 1st and 4th (partially preserved), 5th to 8th (complete) and 9th (preserved only anteriorly). The mandibular symphysis has an interdigitate suture, particularly along its posterior region (Fig. 3.1). Lingual and lateral to the alveolar row there are small neurovascular foramina (Fig. 3.1, 3).

The alveolar margin of the dentary is festooned in dorsal and lateral views (Fig. 3.1, 3). In dorsal view, the fragment is anteriorly wide and spatula-shaped, being its maximum width coincident with the 4 th alveolus. Posteriorly, it slightly narrows up to the level of the 6th and 7th alveoli (Fig. 3.1). In lateral view, the alveolar margin is deeply concave at the level of the 4th dentary tooth (Fig. 3.3). Posteriorly and ventrally to that level, there is a smooth dorsolateral depression for the maxillary teeth during occlusion. Splenial. The splenial forms part of the mandibular symphysis (Fig. 3.1-2), as in basal crocodyliforms, notosuchians, and many long-snouted neosuchians (Clark, 1994). In dorsal and ventral views, the dentary-splenial suture is oriented anteromedially, as in other peirosaurids and long-snout neosuchians (Carvalho et al., 2007; Larsson and Sues, 2007; Leardi and Pol, 2009; e.g., Gavialis gangeticus [MLP 602] pers. obs.). The ventral exposure of both splenials along the symphyseal region is broad, contrasting with derived notosuchians (Pol et al., 2014). Dorsally, the splenial is transversely expanded and slightly concave (Fig. 3.1). The splenial symphysis is wedge-shaped, unlike other notosuchians such as Notosuchus terrestris Woodward, 1896 (MCF PVPH710), and it extends anteriorly to the level of the 6th alveolus as in Gasparinisuchus and Montealtosuchus (Carvalho et al., 2007). In Hamadasuchus the splenial symphysis is more acute and extends to the 7th alveolus (Larsson and Sues, 2007). The splenial expands dorsally behind the mandibular symphysis. The ventral surface of this bone is ornamented (Fig. 3.2), as in Uberabasuchus and possibly Hamadasuchus and Montealtosuchus. The inter-splenial suture is markedly interdigitated (Fig. 3.1-2). In the preserved fragment, the posterior end of the splenial does not reach the alveolar row (Fig. 3.1). Immediately behind the posterior end of the symphyseal facet, part of anterior margin of the foramen intermandibularis oralis is preserved, as observed in uruguaysuchids, baurusuchids and others peirosaurids such as Hamadasuchus (Larsson and Sues, 2007; Montefeltro et al., 2011; Pol et al., 2014).

Articular. The articular is triangular and partially preserved, missing the retroarticular process and a small portion of the prearticular process (Fig. 3.4-5). The prearticular process has a dorsal surface that is markedly concave anteroposteriorly. A well-defined, curved, and anteroventrally oriented crest separates the dorsal and medial surfaces. The medial surface is wider and also concave. The glenoid fossa has an anteromedially triangular projection that is continuous with the previously mentioned crest (Fig. 3.4). The medial and lateral concavities for the quadrate condyles are separated by an oblique ridge. Ventrally, a section of the surface of contact for the angular is preserved. The retroarticular process is damaged but the fracture plane suggests that it was posteroventrally oriented (Fig. 3.5).

Surangular. Only the portion of the surangular adjacent the glenoid fossa is preserved (Fig. 3.4, 6). It contacts the articular laterally, forming the lateral wall of this fossa. Laterally, the surangular forms an elevated posterior buttress for the lateral condyle of the quadrate (Fig. 3.6), a feature shared by several notosuchians such as peirosaurids, sebecids and baurusuchids, but absent in uruguaysuchids and derived notosuchians (Pol et al., 2014). Posterior to this projection, there is a smooth concave surface that corresponds to the lateral portion of the base of the retroarticular process. Part of the surface of contact for the angular is preserved at the posteroventral end. Laterally, the surangular is ornamented and bears a longitudinal prominent ridge (Fig. 3.6) also observed in Montealtosuchus and Uberabasuchus. This ridge forms the dorsal limit of an ornamented depression. On this ridge and lateral to the glenoid fossa (Fig. 3.4, 6) there is an oval concavity for the articula- 
tion with the quadratojugal condyle, indicating the double mandibular articulation (quadrate-articular/surangular and quadratojugal-surangular). This double mandibular joint is a feature shared with Montealtosuchus, Mahajangasuchus insignis Buckley and Brochu, 1999 and Lomasuchus (MCF PVPH-160), as well as many basal mesoeucrocodylians (e.g., Sebecus icaeorhinus Simpson, 1937), but is absent in Uberabasuchus (Carvalho et al., 2007). The glenoid fossa and this concavity are separated by a sharp ridge (Fig. 3.4).

\section{Ornamentation}

The ornamentation of the mandibular fragment is characterized by a smooth dorsolateral depression with neurovascular foramina, and rugose ventral and lateral surfaces characterized by the presence of pits and vermiform grooves (Fig. 3.2-3). This contrasts with some mesoeucrocodylians (e.g., modern crocodylians) that are ornamented with subcircular pits. The surangular fragment has subcircular pits on the lateral prominent ridge, but within the depression these pits are larger. This ornamentation disappears towards the glenoid fossa area (Fig. 3.6). The ornamentation of the maxillary fragment is formed by isolated longitudinal shallow grooves, crests, and circular pits (Fig. 3.1). In the preserved skull table (Fig. 3.6-7, 10-11), the ornamentation consists on deep pits with irregular shapes and crests, which are more evident in the squamosal than in the postorbital. The posterolateral process of the squamosal presents a marked ornamented ledge formed by small pits except at the distal end. The ornamentation of the skull and lower jaw elements of Bayomesasuchus is similar to that of basal notosuchians such as uruguaysuchids and peirosaurids, as well as that of neosuchians.

\section{Dentition}

The preserved teeth show pseudoheterodonty (sensu lordansky, 1973), and two morphologies are distinguished: large teeth with conical crown (caniniform) and small teeth with globose crown (post-caniniform) (Figs. 2.1-3, 4.1). The 4 th dentary tooth is the largest of the preserved tooth-row (Figs. 3.1, 4.1) and is a caniniform with a posteriorly curved apex and cylindrical cross-section. The preserved maxillary teeth have slightly compressed globose crowns (Fig. 2.13). The isolated left caniniform tooth corresponds to the 4th dentary tooth and preserves the apical portion of the
(1)

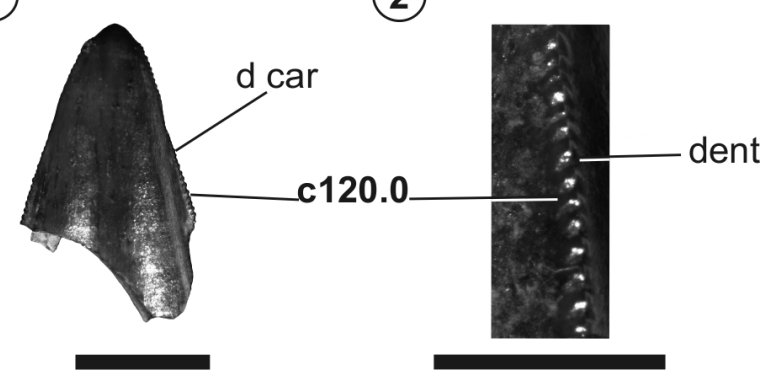

Figure 4. Bayomesasuchus hernandezi gen. et sp. nov., MCF PVPH$822 ; 1-2$, isolated left 4 th dentary tooth in 1 , labial view; 2 , close-up denticle morphology. Abbreviations: dent, denticle; $\mathbf{d}$ car, denticulated carinae; c120.0, synapomorphy of Peirosauridae. Scale bars $=5 \mathrm{~mm}$ (1) and $2.5 \mathrm{~mm}(2)$.

enamel showing convex labial and lingual surfaces (although the latter is slightly flattened). This tooth is ziphodont, a condition present in most notosuchians (e.g., sebecids, baurusuchids) and some eusuchians (Brochu, 2013). The mesial and distal keels are fully denticulated and each keel bears three or four denticles per millimeter (Fig. 4.2), although the denticle density is greater at the apex (Fig. 4.1). The denticle density is lower than that of the peirosaurid Barcinosuchus gradilis Leardi and Pol, 2009 in which there are 11-12 denticles per millimeter. The maxillary post-caniniform teeth have crowns with subequal labial and lingual surfaces separated by a mesiodistal keel. The crown in these teeth is separated from the root by a marked constriction or neck (Fig. 2.1, 3). The preserved anterior maxillary tooth has a triangular crown, whereas in the smaller posterior tooth the crown is low, blunt and spatulate (Fig. 2.1-3). Although poorly preserved, the enamel of these teeth presents denticles on the distal keel. The posteriormost tooth has no preserved denticles.

As in Montealtosuchus, Gasparinisuchus and Hamadasuchus, the anterior dentary alveoli are subcircular, whereas the posterior ones are oval in cross-section (Fig. 3.1, 5). The 1st-4th teeth are implanted in discrete equidistant alveoli, the 5th and 6th alveoli are confluent, and the 7th alveolus is clearly separated but close to the 6th alveolus. The separation between the 7th and 8th alveoli is clear, whereas the 8th and 9th alveoli are confluent because the septum is incomplete. The interalveolar space between the 4th and 5th alveoli is wide (diastema), similar in anteroposterior length 
to the 5th alveolus. The preserved maxillary tooth-row is located along an almost straight alveolar groove (Fig. 2.2). The maxillary alveoli are smaller posteriorly, although the 2nd alveolus is slightly larger. All maxillary teeth are equidistant and close to each other. In the dentary, the 4th alveolus is the largest, the 1st-3rd alveoli are smaller and subequal and are followed in size by the 5th and 6th alveoli (which are equal in size). The 7th and 8th alveoli are slightly smaller than the anterior ones but subequal in size, and finally the 8th alveolus is slightly larger (Fig. 2.1). In Montealtosuchus, Gasparinisuchus and Hamadasuchus the dentary diastema between the 4 th and 5 th alveoli is absent, and the 5 th alveolus is not confluent with the 6 th alveolus in these peirosaurids, contrary to the condition observed in Bayomesasuchus (Larsson and Sues, 2007: fig. 6D; Pol et al., 2014: fig. 40C) (Fig. 5).

\section{DISCUSSION}

Peirosaurid characters in Bayomesasuchus. Most peirosaurids studies were based on skull remains (e.g., Gasparini et al., 1991; Carvalho et al., 2004, 2007; Larsson and Sues, 2007; Martinelli et al., 2012; Sertich and O'Connor, 2014). The taxa Lomasuchus and Rukwasuchus have no comparable mandibular elements, and Barcinosuchus Leardi and Pol, 2009 is very fragmentary compared to Bayomesasuchus. This new taxon (a reconstructed image of the skull of Bayomesasuchus is shown in Figure 7) shares with peirosaurids the following combination of characters (*synapomorphies of Peirosauridae): ziphodont (except in Gasparinisuchus) and pseudoheterodont dentition*, festooned dental margins, ornamentation with pits and grooves, elongated dentary and splenial symphysis, symphyseal region flattened and laterally narrow, splenial dorsal and ventral exposure triangular, postorbital with process descending to anterior otic recess and facet to palpebral bone, squamosal with elongate ornamented posterolateral process*, maxillary tooth-row reaching caudally beyond the anterior margin of the suborbital fenestra, maxillary palate with occlusal depressions*, subvertical rostrum, surangular with prominent posterolateral ridge forming part of the mandibular joint (except in Uberabasuchus).

The autapomorphies that justify Bayomesasuchus hernandezi as a new taxon are: diastema between 4th-5th dentary alveoli, and confluence of 5th and 6th alveoli. As mentioned in the description, in Montealtosuchus, Gasparinisuchus and Hamadasuchus there is no diastema between the 4th-5th alveoli, and the 5th alveolus is not confluent with the 6th alveolus (Fig. 5). In the narrow snouted peirosaurids Itasuchus Price, 1955 and Pepesuchus, the 6th and 7th alveoli are very close to each other but not confluent, with a complete interalveolar septum between them. The same occurs with the next alveolar pair, the 8th and 9th. The 4th-5th, 5th-6th, 7th-8th, and 9th-10th alveoli are separated by a diastema, differing in this from Bayomesasuchus. In living crocodilians (F. Barrios, pers. obs.), when a diastema occurs (e.g., Caiman crocodilus, ZSM 87/1937,
(1)

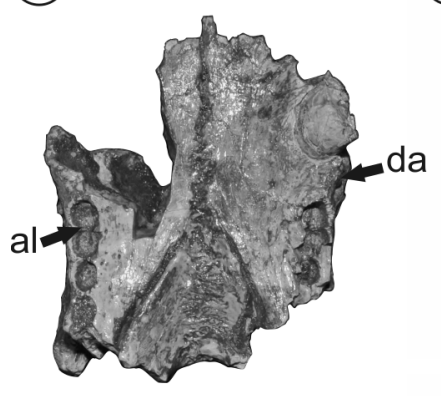

(2)

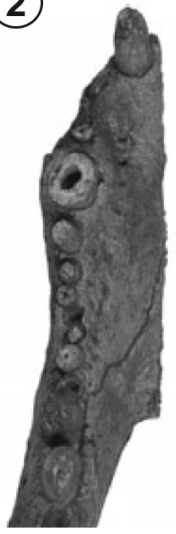

(3)

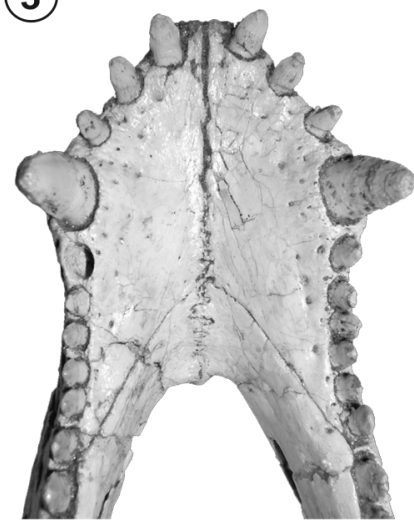

(4)

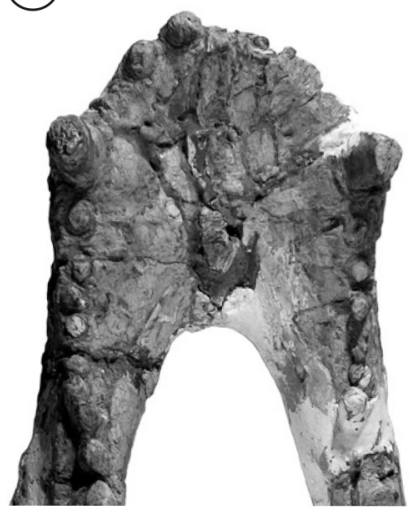

Figure 5. 1, Bayomesasuchus hernandezi gen. et sp. nov. autapomorphies (i.e., da, diastema between 4th-5th; al, confluent alveoli) compared with 2, Hamadasuchus rebouli; 3, Montealtosuchus arrudacamposi, and 4, Gasparinisuchus peirosauroides. 
ZSM 206/1925; Caiman yacare, MACN 8268, MACN 30536, MACN 30555, MLP R 5041, ZSM 163/1929, ZSM 163/1933, ZSM 164/1933, ZSM 167/1933, ZSM 168/1629, ZSM 170/1937; Melanosuchus niger, ZSM 67/1911) and confluence of alveoli (Crocodylus niloticus, PVL 6524; C. crocodilus, ZSM 101/1911; C. yacare, MACN 8262, ZSM 167/1929), they are symmetrically disposed on both mandibular rami, as in Bayomesasuchus, Pepesuchus, and Itasuchus. Therefore, we consider as valid the two autapomorphies listed for Bayomesasuchus hernandezi, as they are features not seen in other peirosaurids.

Phylogenetic analysis. A phylogenetic analysis was undertaken to test the position of Bayomesasuchus within Crocodyliformes. The matrix published by Pol et al. (2014) was modified to include the specimen described here (character scorings in Appendix 1). The resulting matrix, with 412 morphological characters and 110 terminal taxa, was analyzed under maximum parsimony criteria using the software TNT version 1.1 (Goloboff et al., 2008a, b). A heuristic tree search strategy of 10,000 replicates of Wagner trees (random addition sequences) was conducted followed by tree branched reconnection (TBR) branch swapping (holding 10 trees per replicates). The cladistic analysis resulted in 20,380 most parsimonious trees (MPTs) of 1558 steps, with a consistency index (CI) of 0.317 and a retention index (RI) of 0.739 . The analysis supports Peirosauridae as a monophyletic group within Notosuchia and the clade formed by South American peirosaurids + Hamadasuchus as the sister group of the other African notosuchians and Uruguaysuchidae, as proposed by Pol et al. $(2012,2014)$ and Sertich and O'Connor (2014).

The consensus tree placed Bayomesasuchus within Peirosauridae (Fig. 6), forming a polytomy with Hamadasuchus, Gasparinisuchus, Lomasuchus, Montealtosuchus and Uberabasuchus, contrasting the analysis by Sertich and O'Connor (2014), in which Hamadasuchus is deeply nested among other peirosaurids. In previous phylogenetic analyses Hamadasuchus is shown either as the sister group of the South American peirosaurids (Larsson and Sues, 2007; Pol et al., 2014) or forming a polytomy with the South American relatives (Turner and Sertich, 2010; Pol et al., 2012). On the other hand, Mahajangasuchus Buckley and Brochu, 1999 + Kaprosuchus Sereno and Larsson, 2009 and Stolokrosuchus Larsson and Gado, 2000 are depicted as successive sister groups of peirosaurids, as in Pol et al. (2014) and partially in Sertich and O'Connor (2014), where Stolokrosuchus has a terminal position.

The present analysis reveals five unambiguous synapomorphies diagnosing Peirosauridae: tooth with denticulate carinae (character 120.0) (absent in the holotype of Gasparinisuchus); nasal-maxilla suture nearly parallel (character 128.0); supraoccipital not exposed in skull roof (character 171.0); foramen present in perinarial depression of premaxilla (character 237.1); maxilla-palatine suture with palatine anterior end slightly invaginate (character 243.2); prominent depression on the maxillary palate at the level of the sixth or seventh alveolus (character 396.1) (see Pol et al., 2014). In some MPTs two other character states provide unambiguous synapomorphies of peirosaurids: choanal groove partially septate (character 69.1) and longitudinal ridge along the dorsolateral surface of surangular (character 220.1). Of all these synapomorphies, only three can be recognized in the holotype of Bayomesasuchus hernandezi gen. et sp. nov.: ziphodont tooth, depression on the maxillary palate at the level of the sixth or seventh alveolus, and longitudinal ridge dorsolateral to surangular.

The fragmentary nature of the cranial remains of Bayomesasuchus and the lack of postcranial remains precludes the resolution of the polytomy obtained for the studied peirosaurids. Phylogenetic relationships of other mesoeu-

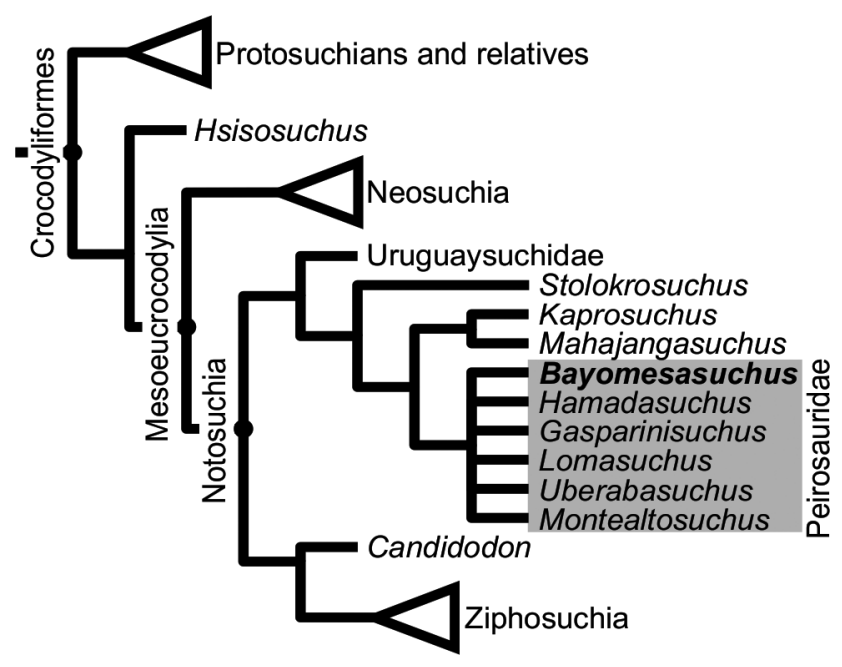

Figure 6. Strict consensus tree, in gray the node including Bayomesasuchus hernandezi gen. et $\mathrm{sp}$. nov. $\mathrm{Cl}=0.308 ; \mathrm{RI}=0.745$. 
(1)

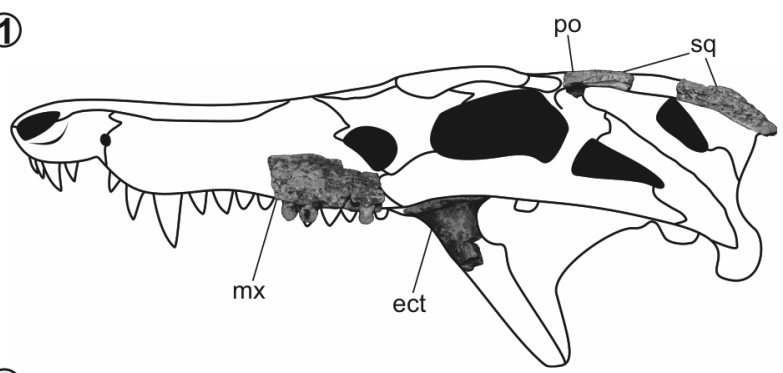

(2)

(3)

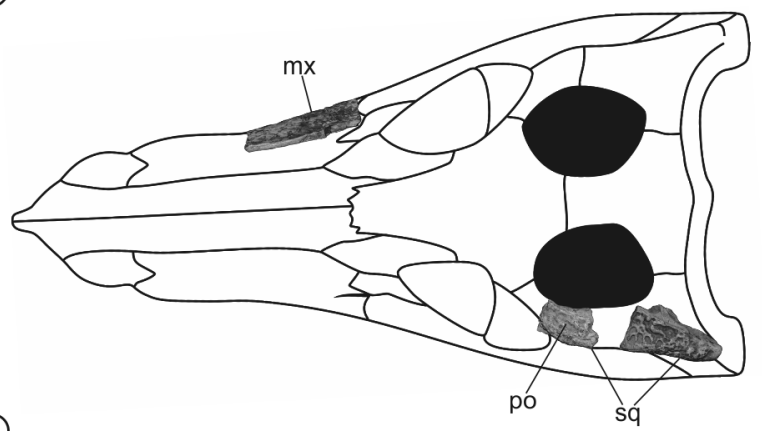

(4)
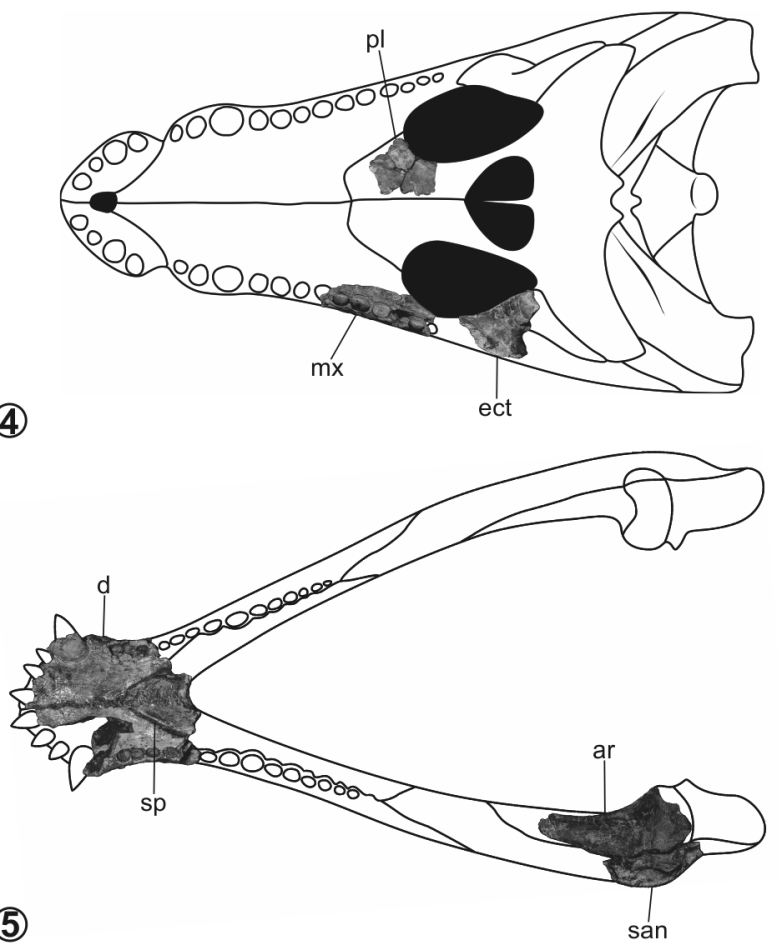

(5)

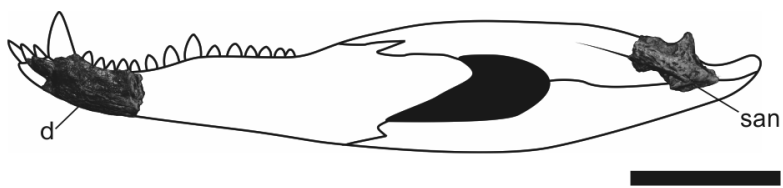

Figure 7. Bayomesasuchus hernandezigen. et sp. nov. schematic skull reconstruction; $1-3$, skull in 1, left lateral (maxilla mirrored), 2, dorsal, and 3, palatal views; 4-5, mandible in 4, dorsal (articular and surangular mirrored), and 5, left lateral views (surangular mirrored). Abbreviations: ar, articular; d, dentary; ect, ectopterygoid; mx, maxilla; pl, palatine; po, postorbital; san, surangular; sp, splenial; sq, squamosal. Scale bar $=5 \mathrm{~cm}$. crocodylians with peirosaurid affinities (e.g., Mahajangasuchus, Stolokrosuchus, Kaprosuchus, and Trematochampsa Buffetaut, 1974) is controversial (Buckley and Brochu, 1999; Larsson and Gado, 2000; Larsson and Sues, 2007; Sereno and Larsson, 2009; Turner and Sertich, 2010; Pol et al., 2012; Sertich and O'Connor, 2014) and further studies including other peirosaurids (e.g., Barcinosuchus) and probable peirosaurids (e.g., Pepesuchus, and Itasuchus) need to be carried out in order to better understand a more comprehensive phylogenetic context of Peirosauridae relationships. Stratigraphic precedence and implications. Peirosaurids are currently known from South America and Africa, indicating a Gondwanan distribution for the group. Peirosauridae is known from the Cretaceous of South America (Argentina and Brazil), and Africa (Morocco, Niger and Tanzania) (Gasparini, 1982; Gasparin et al., 1991; Larsson and Gado, 2000; Larsson and Sues, 2007; Sertich and O'Connor, 2014). The oldest records of the family are from the Aptian of Africa: Rukwasuchus yajabalijekundu (Galula Formation, Aptian-Cenomanian), Hamadasuchus rebouli (Kem Kem beds, Albian-Cenomanian), and Patagonia: Barcinosuchus gradilis (Cerro Barcino Formation, Aptian-Albian) (Larsson and Sues, 2007; Leardi and Pol, 2009; Sertich and O'Connor, 2014).

The two named peirosaurids from the Neuquén Group (Lomasuchus palpebrosus and Gasparinisuchus peirosauroides) are from Late Cretaceous units, the Portezuelo, Bajo de la Carpa, and Anacleto formations (late Turonian-Campanian), which form the Río Neuquén and Río Colorado subgroups. Until now, peirosaurid materials from the Cerro Lisandro Formation (mid-upper Turonian) from the underlying Río Limay Subgroup (Cenomanian-Turonian; Garrido, 2010) were restricted to isolated teeth, plates/scutes, and other poorly informative fragments from the Cerro Bayo Mesa locality (Coria et al., 1996; Garrido, 2000). Bayomesasuchus hernandezi is the first peirosaurid species identified not only from the Cerro Lisandro Formation, but also from the Río Limay Subgroup, representing the oldest record (mid Turonian; Garrido, 2010) of Peirosauridae in the Neuquén Basin and increasing the crocodyliform diversity of the Neuquén Group.

The resultant polytomy between African and South American peirosaurids (Fig. 6), however, reinforces a Gondwana distribution of the Peirosauridae clade, and does not 
support the hypothesis of a South American endemic peirosaurid clade (Carvalho et al., 2007). The obtained topology provides a clear faunal link between these two landmasses during the Cretaceous. New discoveries are needed to improve our understanding of the paleobiogeographic history of Peirosauridae in Gondwana during this period.

\section{CONCLUSIONS}

The presence of the new small-size peirosaurid Bayomesasuchus hernandezi improves the systematic understanding of this group in South America, while increasing the diversity of Patagonian crocodyliforms. The new taxon is also important as it is the first peirosaurid identified from the Río Limay Subgroup, being the oldest record of Peirosauridae from the Neuquén Basin. Although the specimen is fragmentary, the preserved material allowed a phylogenetic analysis that shows Bayomesasuchus closely related to the African (e.g., Hamadasuchus) and the South American peirosaurids (Uberabasuchus, Montealtosuchus, Lomasuchus and Gasparinisuchus), reinforcing the Gondwanan distribution of Peirosauridae.

\section{ACKNOWLEDGMENTS}

We thank the former Museo Carmen Funes Director, L. Rikemberg, the Municipalidad de Plaza Huincul, and Secretaría de Cultura de la Provincia de Neuquén, for supporting this study. To D. Hernández (Municipalidad de Plaza Huincul and former technician of MCF) who greatly collaborated with the necessary logistics. We thank $A$. Garrido and B. Boilini (MOZ) and M. Reguero (MLP) for the access to the collection under their care. A. Garrido also analyzed and discussed the stratigraphic provenance of the specimen. A. Martinelli (CPP) kindly provided the photographs of Uberabasuchus. Finally, we thank the editor D. Pol, and 3 anonymous reviewers whose comments greatly improved this manuscript.

\section{REFERENCES}

Barrios, F., and Bona, P. 2015. Sobre un Nuevo Mesoeucrocodylia (Crocodyliformes) del Cretácico de Río Negro, Patagonia. Ameghiniana, Suplemento Resúmenes 52: 4R.

Brochu, C. 2013. Phylogenetic relationships of Palaeogene ziphodont eusuchians and the status of Pristichampsus Gervais, 1853. Earth and Environment Science Transactions of the Royal Society of Edinburgh 103: 1-30.

Buckley, G.A., and Brochu, C. 1999. An enigmatic new crocodile from the Upper Cretaceous of Madagascar. Special Papers in Palaeontology 60: 149-175.

Buffetaut, E. 1974. Trematochampsa taqueti, un crocodilien nouveau du Sénonian inférieur du Niger. Comptes Rendus de l'Académie des Sciences 279: 1749-1752.

Buffetaut, E. 1994. A new crocodilian from the Cretaceous of southern Morocco. Comptes Rendus de I'Académie des Sciences
319: 1563-1568.

Campos, D.A., Oliveira, G.R., Figueiredo, R.G., Riff, D., Azevedo, S.A.K., Carvalho, L.B., and Kellner, A.W.A. 2011. On a new peirosaurid crocodyliform from the Upper Cretaceous, Bauru Group, southeastern Brazil. Anais da Academia Brasileira de Ciências 83: 317-327.

Candeiro, C.R., and Martinelli, A.G. 2006. Paleogeographical and chronostratigraphical distribution of mesoeucrocodylian species from the Upper Cretaceous beds from Bauru (Brazil) and Neuquén (Argentina) groups, southern South America. Journal of South America earth Sciences 22: 116-129.

Carvalho, I.S., Ribeiro, L.C., and Ávila, L. 2004. Uberabasuchus terrificus sp. nov. a new Crocodylomorpha from the Bauru Basin (Upper Cretaceous) Brazil. Gondwana Research 7: 975-1002.

Carvalho, I.S., Vasconcellos, F.M., and Tavares, S.A.S. 2007. Montealtosuchus arrudacamposi, a new peirosaurid crocodile (Mesoeucrocodylia) from the Late Cretaceous Adamantina Formation of Brazil. Zootaxa 1607: 35-46.

Carvalho, I.S., Gasparini, Z.B., Salgado, L., Vasconcellos, F.M., and Marinho, T.S. 2010. Climate's role in the distribution of the Cretaceous terrestrial Crocodyliformes throughout Gondwana. Palaeogeography, Palaeoclimatology, Palaeoecology 297: 252262.

Clark, J.M. 1986. [Phylogenetic relationships of the crocodylomorph archosaurs. Ph.D. dissertation, University of Chicago, Chicago, 556 p. Unpublished.].

Clark, J.M. 1994. Patterns of evolution in Mesozoic Crocodyliformes. In: N.C. Fraser, and H.D. Sues (Eds.), The Shadow of the Dinosaurs: Early Mesozoic Tetrapods. Cambridge University Press, New York, p. 84-97.

Coria, R.A., Cladera, G., and Salgado, L. 1996. Sobre una nueva localidad fosilífera en la Formación Río Limay? Cretácico Superior temprano, en la localidad de Cerro Bayo Mesa, Provincia de Neuquén. Ameghiniana, Suplemento Resúmenes 33: 463.

Garrido, A.C. 2000. [Estudio estratigráfico y reconstrucción paleoambiental de las secuencias fosiliferas continentales del Cretácico Superior en las inmediaciones de Plaza Huincul, provincia del Neuquén. Trabajo final para el Título de Grado, Escuela de Geología de la Facultad de Ciencias Exactas, Físicas y Naturales. Universidad Nacional de Córdoba, Córdoba, 78 p. Unpublished.].

Garrido, A.C. 2010. Estratigrafía del Grupo Neuquén, Cretácico Superior de la Cuenca Neuquina (Argentina): nueva propuesta de ordenamiento litoestratigráfico. Revista del Museo Argentino de Ciencias Naturales 12: 121-177.

Gasparini, Z.B. 1971. Los Notosuchia del Cretácico de América del Sur como un nuevo Infraorden de los Mesosuchia (Crocodilia). Ameghiniana 8: 83-103.

Gasparini, Z.B. 1982. Una nueva familia de cocodrilos zifodontes cretácicos de América del Sur. $V^{\circ}$ Congreso Latinoamericano de Geología (Buenos Aires), Actas 4: 317-329.

Gasparini, Z.B., Chiappe, L., and Fernández, M. 1991. A new Senonian peirosaurid (Crocodylomorpha) from Argentina and a synopsis of the South American Cretaceous crocodilians. Journal of Vertebrate Paleontology 11: 316-333.

Goloboff, P.A., Farris, J.S., and Nixon, K.C. 2008a. TNT: Tree Analysis Using New Technology, version 1.1 (Willi Hennig Society Edition). Program and documentation available at http://www.zmuc.dk/public/phylogeny/tnt.

Goloboff, P.A., Farris, J.S., and Nixon, K.C. 2008b. TNT, a free program for phylogenetic analysis. Cladistics 24: 774-786.

Hay, O.P. 1930. Second Bibliography and Catalogue of the Fossil Vertebrata of North America. Carnegie Institution of Washington Publication 390, Volume 2, Washington DC 2, 1094 p. 
Iordansky, N.N. 1973. The skull of the Crocodilia. In: C.A. Gans, and T.S. Parsons (Eds.), Biology of the Reptilia. Vol. 4. Academic Press, London, p. 201-260.

Larsson, H.C.E., and Gado, B. 2000. A new Early Cretaceous crocodyliform from Niger. Neues Jahrbuch für Geologie und Paläontologie, Abhandlungen 217: 131-141.

Larsson, H.C.E., and Sues, H.D. 2007. Cranial osteology and phylogenetic relationships of Hamadasuchus rebouli (Crocodyliformes: Mesoeucrocodylia) from the Cretaceous of Morocco. Zoological Journal of the Linnean Society 149: 533-567.

Leanza, H.A., Apesteguía, S., Novas, F.E., and de la Fuente, M.S. 2004. Cretaceous terrestrial beds from the Neuquén Basin (Argentina) and their tetrapod assemblages. Cretaceous Research 25: 61-87.

Leardi, J.M., and Pol, D. 2009. The first crocodyliform from the Chubut Group (Chubut Province, Argentina) and its phylogenetic position within basal Mesoeucrocodylia. Cretaceous Research 30: 1376-1386.

Lio, G., Juarez Valieri, R., Filippi, L., Agnolin, F.L., and Rosales, D. 2014. Peirosaurid (Crocodyliformes) remains from the Portezuelo Formation (Turonian-Coniacian) at Añelo locality, Neuquén. Ameghiniana, Suplemento Resúmenes 51: 15R.

Martinelli, A., Sertich, J., Garrido, A.C., and Praderio, A.M. 2012. A new peirosaurid from the Upper Cretaceous of Argentina: Implications for specimens referred to Peirosaurus torminni Price (Crocodyliformes: Peirosauridae). Cretaceous Research 37: 191-200.

Montefeltro, F.C., Larsson, H.C.E., and Langer, M.C. 2011. A new baurusuchid (Crocodyliformes, Mesoeucrocodylia) from the Late Cretaceous of Brazil and the phylogeny of Baurusuchidae. PLoS ONE 6: e21916, doi:10.1371/journal.pone.0021916

Pol, D., and Gasparini, Z.B. 2007. Crocodyliformes. In: Z.B. Gasparini, L. Salgado, and R.A. Coria (Eds.), Patagonian Mesozoic Reptiles, Indiana University Press, Bloomington, p. 116-142.

Pol, D., Leardi, J.M., Lecuona, A., and Krause, M. 2012. Postcranial anatomy of Sebecus icaeorhinus (Crocodyliformes, Sebecidae) from the Eocene of Patagonia. Journal of Vertebrate Paleontology 32: 328-354.

Pol, D., Nascimento, P.M., Carvalho, A.B., Riccomini, C., PiresDomingues, R.A., and Zaher, H. 2014. A new Notosuchian from the Late Cretaceous of Brazil and the Phylogeny of Advanced Notosuchians. PLoS ONE 9: e93105. doi:10.1371/journal.pone.0093105.

Price, L.l. 1955. Novos crocodilídeos dos Arenitos da Serie Bauru, Cretáceo do Estado de Minas Gerais. Anais Academia Brasileira de Ciências 27: 487-498.
Sereno, P.C., and Larsson, H.C.E. 2009. Cretaceous crocodyliforms from the Sahara. Zookeys 28: 1-143.

Sertich, J.J.W., and O־Connor, P.M. 2014. A new crocodyliform from the middle Cretaceous Galula Formation, southwestern Tanzania. Journal of Vertebrate Paleontology 34: 576-596.

Shute, C.C.D., and Bellairs, Ad'A. 1955. The external ear in Crocodilia. Proceedings of the Zoological Society of London 124: 741748.

Simpson, G.G. 1937. New reptiles from the Eocene of South America. American Museum Novitates 927: 1-3.

Turner, A.H., and Sertich, J.J.W. 2010. Phylogenetics history of Simosuchus clarki (Crocodyliformes: Notosuchia) from the Late Cretaceous of Madagascar. Journal of Vertebrate Paleontology 30: 177-236.

Walker, A.D. 1970. A revision of the Jurassic Hallopus victor(Marsh), with remarks on the classification of crocodiles. Philosophical Transactions of the Royal Society of London B 257: 323-372.

Whetstone, K.N., and Whybrow, P.J. 1983. A "cursorial" crocodilian from the Triassic of Lesotho (Basutoland), southern Africa. Occasional Papers of the Museum of Natural History, University of Kansas 106: 1-37.

Woodward, A.S. 1896. On two Mesozoic crocodilians (Notosuchus genus novum) and (Cynodontosuchus genus novum) from the red sandstones of the territory of Neuquen (Argentine Republic). Anales del Museo de La Plata 4: 1-20.

doi: 10.5710/AMGH.03.09.2015.2903

Submitted: March $7^{\text {th }}, 2015$

Accepted: September $3^{\text {rd }}, 2015$ 